\title{
属性情報を考慮した消費者行動パターン抽出の ための非負値多重行列因子分解法 \\ Non-negative Multiple Matrix Factorization for Consumer Behavior Pattern Extraction by Considering Attribution Information
}

\author{
幸島 王宏 \\ 日本電信電話株式会社 NTT サービスエボリューション研究所 \\ NTT Service Evolution Laboratories, NTT Corporation \\ kohjima.masahiro@lab.ntt.co.jp \\ 松林 達史 \\ (同上) \\ matsubayashi.tatsushi@lab.ntt.co.jp \\ 澤田 宏
Hiroshi Sawada \\ (同上) \\ sawada.hiroshi@lab.ntt.co.jp
}

keywords: pattern extraction, non-negative matrix factorization, NMF, attribution information, linear constraint

\begin{abstract}
Summary
In this paper, we propose a new Non-negative Matrix Factorization (NMF) method for consumer behavior pattern extraction. NMF is one of the pattern extraction method and is formulated to factorize a non-negative matrix into the product of two factor matrices. Since various types of datasets are represented by non-negative matrices, NMF could be applied in wide range of research fields including marketing science, natural language processing and brain signal processing. However, more effective extension method is required in a purchase log analysis in marketing operation since marketer needs to extract interpretable patterns from sparse matrix in which most of the elements are zero. Therefore, we propose Non-negative Micro Macro Mixed Matrix Factorization (NM4F) which uses attribution information of both users and items to improve interpretability and capability to deal with sparsity. NM4F is formulated as a method which could simultaneously factorize multiple matrices using shared factor matrices and linear constraint between factor matrices. This formulation enables to increase an amount of available information and to extract consistent patterns with several different aspect. We derive the parameter estimation algorithm by multiplicative update rules. We confirmed the effectiveness of the proposed method in terms of both quality and quantity by using real consumer panel dataset. In addition, we discuss a relation between extracted patterns by the visualization results using graph drawing.
\end{abstract}

\section{1. は じめ に}

消費者の購買行動パターンの抽出は, 企業にとって戦略 立案に関わる重要なタスクである. 例えば企業のマーケ ティング担当者は, 市場の消費者をセグメントに分割し, 各セグメントの特性を調べることで, 新商品のターゲット とする消費者群の決定やプロモーション計画の策定など の戦略立案を実施している [阿部 05]. 例えば, プロモー ション計画策定のための実際の現場作業には次のような 工程が挙げられる.

Act1 セグメンテーション 消費者の性別, 年齢など を表すデモグラフィック変数や, ライフスタイル や購買パターンをもとに, 市場の消費者をセグメ ントに分割 (消費者をクラスタリング)する.

Act2 プロファイリング 各セグメントに属する消費 者の代表的な購買パターンや属性情報等を調査す
ることでセグメントの特性を調べる. 例えば, ど のようなカテゴリの商品を頻繁に購入するユーザ 群であるのか, またどのようなユーザ属性が多く, 有効な広告手段が存在するか否かを把握する.

$\operatorname{Act3}$ ターゲッティング・ プランニング 外部要因等

も考慮したうえで, セグメンテーションおよびプ ロファイリング結果を利用し, ターゲットとする セグメントを決定し, 施策内容を考える.

特に近年では, デモグラフィック変数では構築できないセ グメンテーション結果を得るために, 消費者の購買履歴を 直接利用してユーザをクラスタリングするアプローチも 注目されつつある. 現場の負担を軽減させるため, また作 業の工程で人手を介することによる主観を排除するため, 上記に代表される作業を自動化しマーケティングの現場 で利用可能な技術を構築することが必要とされている. 
近年, 行列表現が可能なデータを解析する手法として行 列因子分解に基づく手法が注目を集めており,パターン抽 出や推薦システムなどに利用されている [Lee 99, Koren 09, Purushotham 12]. 消費者の購買履歴も行がユーザ, 列 か商品, 要素を購入数と設定することで行列表現が可能で あり, この手法が適用可能である. 行列因子分解法は, 行 列データを低次の因子行列の積で近似する手法として定 式化される. 購買履歴の例では, 得られる各因子行列が光

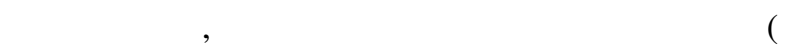
与度) を表しており, ユーザと商品の同時クラスタリング 手法であるとみなすこともできる. しかし, 行列因子分解 法を消費者の購買行動パターン抽出に適用し, 企業での 戦略立案等にこれまで以上に役立てるためには, 従来手 法の発展が必要とされている.

発展の1つの方向性には, スパースなデータへの対応が 挙げられる. 日々新たに新商品か投入されている今日, 購 買履歴で利用できるデータは利用履歴の多い消費者に限 定したとしても消費者の趣味趣向等が反映されたパター ンを抽出するうえで十分量であるとは限らない. 例えば スーパーマーケットのように, 商品数が1万を超えるよ うな日用品を扱う際には, データのスパース性によるパ ターン抽出の困難による問題は常に生じていると考える. したがってスパースなデータからも安定してパターンを 抽出できる必要がある. 異なる発展の方向性としては, 出 力の解釈性の向上が挙げられる. 多種多樣な行動を行う消 費者から抽出されたパターンは必ずしも容易に解䣋でき るものとは限らず, また, 弚のパターンが何らかの例外的 な行動によるものかどうかの判断も一般に容易でない.し たがって, 解釈や判断を助ける仕組み, 例えば複数のデー タを利用し, ユーザ属性などの情報をパターンに付与す ることなどが必要となる.

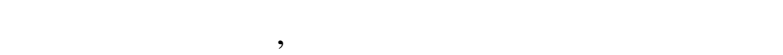
る行列因子分解法を提案する. 提案手法は, 購買履歴に加 えて年代や職業などのユーザ属性やカテゴリなどの商品 属性に関する情報を利用する. これらの情報を用いて作 成する行列を入力に追加し, 提案手法を複数の行列の同 時因子分解を行う, ユーザと商品, ユーザ属性, カテゴリ の同時クラスタリング手法として定式化する. 图 1 に提 案手法の出力のイメージ図を示す. 提案手法の定式化の 鍵は, 因子行列の共有と因子行列間の線形制約の導入に ある. ユーザ, 商品に対応する因子行列を複数の行列の分 解に共通で利用することにより，因子行列の推定に利用 できる情報を増やすことができる.これが因子行列の推 定精度の向上, すなわちスパースデータからの安定した パターン抽出を可能とする. また，因子行列間の制約条件 の導入により, 図 1 のパターン 2 で拡大表示しているよ うに, 各パターン内で同一カテゴリの商品の寄与度の和 とカテゴリの寄与度が一致するという条件を課す. これ は, あるカテゴリに属する商品の寄与度が大きいパター ンは, 弚のカテゴリ自体の寄与度が大きい值をとるとい

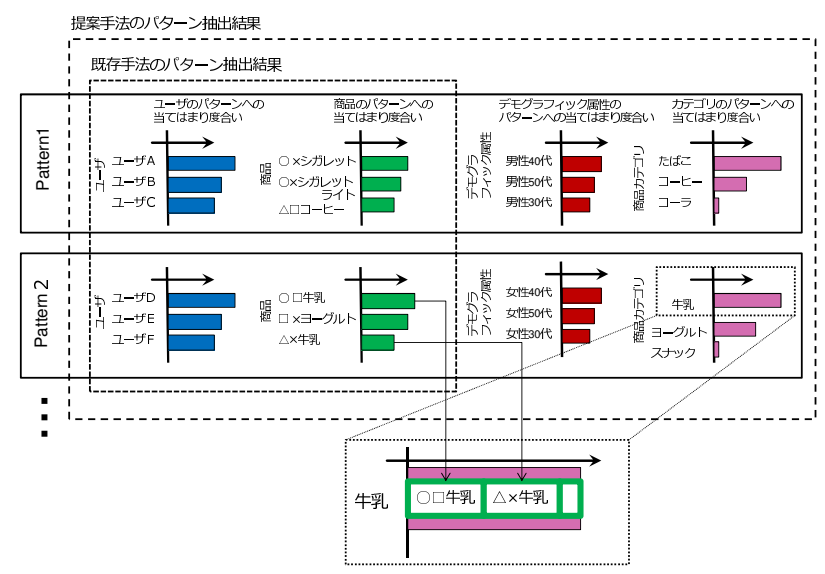

図 1 出力のイメージ図

う出力が持つべき性質を導く.これにより, 商品の寄与度 とカテゴリの寄与度の対応関係を考慮することで, 解釈 性を向上させた出力高度化が可能となる. なおここで言 う解釈性の向上とは、整合性を保たれないことによる結 果の解釈が困難となることを防いでいる」ということを 指す. 上記の実現により,消費者群のセグメンテーション と光の代表的な属性を付与する, という前述したマーケ ティングにおける作業工程 Act1,2 を自動化し,一挙に行 うことも可能となる.

行列分解の代表的手法には, 確率的行列分解 (Probabilistic Matrix Factorization, PMF)[Salakhutdinov 12], 非負値 行列分解 (Non-negative Matrix Factorization, NMF)[Lee

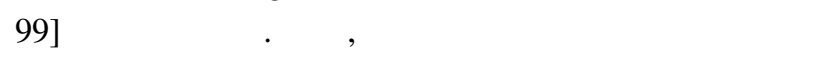
つの行列データを想定しているため, 複数のデータを入力 として利用可能な拡張手法 [Lee 10, Cai 11, Purushotham 12, Takeuchi 13, 幸島 13] も提案されている. しかし, こ れらの手法も, 提案手法とは異なり, 商品と光のカテゴリ といった因子行列間の対応関係が正しく考慮されていな い. したがって, 例えば, 牛乳カテゴリに属する商品の寄 与度が大きいパターンであるにもかかわらず, 牛乳カテ ゴリ自体の弚のパターンへの寄与度が小さい, という整 合性の保たれない出力が得られる場合がある. このこと は後述の実験により確かめられる. 整合性の保たれない 出力は, パターンの解釈を行う際の阻害要因となりうる ものであり, 提案手法は, 因子行列間の線形制約条件を利 用した定式化により,この問題を解決する.

本研究の貢献は, 次のようにまとめられる.

- 因子行列の共有と因子行列間の線形制約導入により, 属性情報との対応関係を考慮できる非負值多重行列 因子分解手法の構築

・乗法更新則による上記提案手法の効率的なパラメタ 推定アルゴリズムの導出

・上記提案手法の調査パネルデータへの適用により得 た消費者行動パターンの可視化

本稿の構成は次の通りである. 2 章で関連研究, 3 章で 問題設定について述べる. 4 章で提案手法の説明を行い, 
5 章では提案手法のためのアルゴリズムを導出する. 6 章 か実験, 7 章がまとめである.

\section{2. 関 連 研 究}

\subsection{Non-negative Matrix Factorization}

非負值行列因子分解 (NMF) は音源分離, 文書分類, 画 像欠損補完など多樣なデータ解析において利用されて いるパターン抽出手法の一つである [Lee 99]. 因子行 列のとりうる值に非負值制約を導入している点が確率 的行列分解 (PMF)[Salakhutdinov 12] と異なる点であり, 解釈可能なパターンが抽出されやすい傾向があること が報告されている. NMF は損失関数を適切に選択する ことで多樣な推定アルゴリズムが導出可能であり [Lee 01, Cichocki 09], 特に一般化カルバック距離を損失関数に 利用するNMF と, 文書分類などで近年広く利用される確 率的潜在意味解析 [Hoffman 99], 潜在的ディリクレ配分法 [Blei 03] とは深い関係性が存在することも指摘されている [Ding 08]. 他にもベイズ的アプローチを採用した変分べ イズ NMF(Variational Bayesian NMF, VBNMF)[Cemgil 08]や, クラスタ数自動決定が可能なノンパラメトリック ベイズ拡張手法 [Hoffman 10] の有効性なども報告されて いる. VBNMFは事前分布を取り入れることで過学習を 防ぎ,スパースなデータにおいても有効な手法である. 6 章では対比手法として VBNMF を利用する.

\subsection{Non-negative Matrix Factorization with Auxiliary Information}

NMF はある一つの非負値行列を分解する手法であるが， これに補助情報を入力として利用する拡張手法も幾つか 提案されている. 非負値多重行列因子分解 (Non-negative Multiple Matrix Factorization, NMMF)[竹内 12, Takeuchi 13] は代表的な手法の 1 つであり, 解析対象の行列と補助 行列を因子行列を共有しながら同時に分解する方法であ る. また, 各商品 (ユーザ) の所属クラスタに関する補助 情報を教師情報として利用する半教師付き $\mathrm{NMF}$ (Semisupervised NMF, SNMF)[Lee 10]や, 各商品 (ユーザ) が ノードに対応するグラフ光のものを補助情報として利用 するアプローチ [Cai 11] も提案されている. これら補助 情報を利用した行列因子分解は，属性情報を利用する提 案手法のベースとなっている技術であり，6 章では対比 手法として NMMF を用いる. 4 章でNMMF の定式化を 示す.

\section{3. 問 題 設 定}

本研究では, 購買データを各要素の値が 0 以上となる 購買行列 $\boldsymbol{X}:=\left\{x_{i j}\right\}_{i, j=1}^{I, J}$ で表現する. 購買行列の要素 $x_{i j}$ はユーザ $i$ の商品 $j$ の購入数を表す. $I$ が総ユーザ数, $J$ が総商品数である. したがって購買行列 $\boldsymbol{X}$ は, 各行, 各
列が特定のユーザと商品に対応していることとなる.

ユーザ, 商品と属性との対応関係は, 図 2 に示す, 対応 関係の存在する属性の要素間に枝をもつ二部グラフとし て表現できる. 二部グラフは一般に行列で表現すること が可能である. 商品とカテゴリとの対応関係を定める行 列 $\boldsymbol{W}$ を, $\boldsymbol{W}$ の要素 $w_{j k}$ は商品 $j$ に対応するノードとカ テゴリ $k$ に対応するノードに枝が存在するとき 1 , 光うで なければ 0 をとる行列として定義する. 同樣にユーザと グループとの対応関係を定める行列を $V$ で定義する.

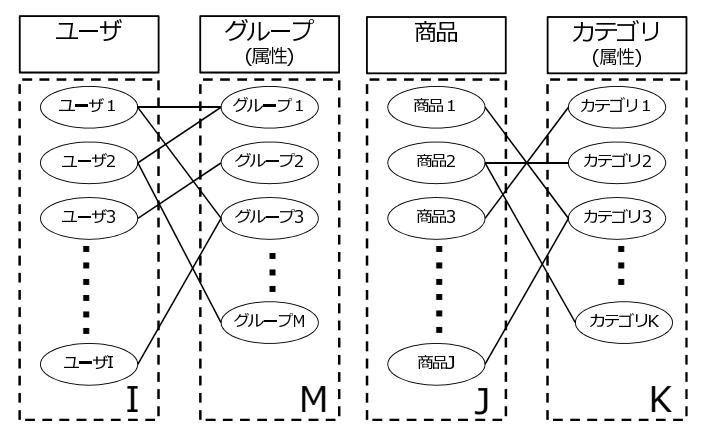

図 2 属性を付与する二部グラフ

本研究では, ユーザとグループとの対応関係を与える行 列 $\boldsymbol{V}$, 商品とカテゴリとの対応関係を与える行列 $\boldsymbol{W}$ と， 图 3 に示されるユーザ-商品行列 $\boldsymbol{X}$, ユーザ-カテゴリ購 買行列 $\boldsymbol{Y}$, グループ-商品購買行列 $\boldsymbol{Z}$ という3つの購買 行列が利用可能であると仮定する. なお, 購買行列 $\boldsymbol{Y}, \boldsymbol{Z}$ は光れ午れ $\boldsymbol{Y}$ の要素 $y_{i k}$ がユーザ $i$ のカテゴリ $k$ の商品 の購入数, $\boldsymbol{Z}$ の要素 $z_{m j}$ がグループ $m$ の商品 $j$ の商品の 購入数を表す行列である. 入力として利用する行列を表 1 にまとめて記す.

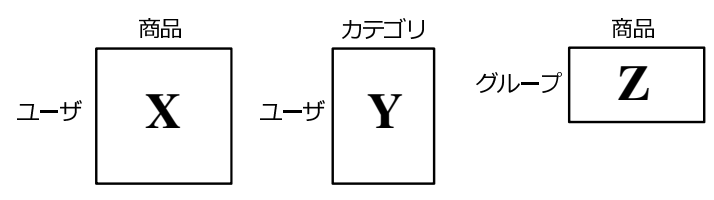

図 3 購買行列一覧

表 1 入力行列一覧

\begin{tabular}{lll}
\hline \hline 記号 & 記述 & 変域 \\
\hline $\boldsymbol{X}$ & ユーザ-商品購買行列 & $\mathbb{R}_{+}^{I \times J}$ \\
$\boldsymbol{Y}$ & ユーザ-カテゴリ購買行列 & $\mathbb{R}_{+}^{I \times K}$ \\
$\boldsymbol{Z}$ & グループ-商品購買行列 & $\mathbb{R}_{+}^{M \times J}$ \\
$\boldsymbol{V}$ & ユーザ-グルーブ対応行列 & $\{0,1\}^{I \times M}$ \\
$\boldsymbol{W}$ & 商品-カテゴリ対応行列 & $\{0,1\}^{J \times K}$ \\
\hline
\end{tabular}

\section{4. 提 案 手 法}

この章では提案手法について述べる. まずはじめに提 案手法の考える行列分解形を説明し, 兴の後線形制約と, 定式化について述べる. 
$4 \cdot 1$ 行 列 分 解 形

提案手法では購買行列 $X, Y, Z$ の次式の行列分解を考 える.

$\boldsymbol{X} \approx \boldsymbol{A} \boldsymbol{B}^{T}, \boldsymbol{Y} \approx A \boldsymbol{C}^{T}, \boldsymbol{Z} \approx \boldsymbol{B} \boldsymbol{D}^{T}$

ただし, 行列 $\boldsymbol{A}, \boldsymbol{B}, \boldsymbol{C}, \boldsymbol{D}$ は乥れ光れ要素が非負の行列 $\boldsymbol{A}:=\left\{a_{i r}\right\}_{i, r=1}^{I, R}, \boldsymbol{B}:=\left\{b_{j r}\right\}_{j, r=1}^{J, R}, \boldsymbol{C}:=\left\{c_{k r}\right\}_{k, r=1}^{K, R}, \boldsymbol{D}:=$ $\left\{d_{m r}\right\}_{m, r=1}^{M, R}$ である. 直感的には, これは総クラスタ数を $R$ と指定した下でのユーザと商品, カテゴリ, グループの 同時クラスタリングを行っているとみなすことができる. $\boldsymbol{A}$ の要素 $a_{i r}$ がユーザ $i$ のクラスタ $r$ への寄与度, $\boldsymbol{B}$ の 要素 $b_{j r}$ か商品 $j$ のクラスタ $r$ への寄与度を表す. 同樣に $\boldsymbol{C}$ の要素 $c_{k r}$ がカテゴリ $k$ のクラスタ $r$ への寄与度, $\boldsymbol{D}$ の要素 $d_{m r}$ がグループ $m$ のクラスタ $r$ への寄与度を表 す. 寄与度は一般に $\sum_{r} a_{i r}=1$ を満たすことはなく, 確 率値となっているわけではないことに注意する.式 (1)の 近似 $\approx$ の尺度については次節で述べる. 提案手法の出力 となる行列と关の名称の一覧を表 2 に記す.

表 2 出力行列一覧

\begin{tabular}{lll}
\hline \hline 記号 & 記述 & 変域 \\
\hline $\boldsymbol{A}$ & ユーザ特徵行列 & $\mathbb{R}_{+}^{I \times R}$ \\
$\boldsymbol{B}$ & 商品特徵行列 & $\mathbb{R}_{+}^{J \times R}$ \\
$\boldsymbol{C}$ & カテゴリ特徵行列 & $\mathbb{R}_{+}^{K \times R}$ \\
$\boldsymbol{D}$ & グルーブ特徵行列 & $\mathbb{R}_{+}^{M \times R}$ \\
\hline
\end{tabular}

\section{$4 \cdot 2$ 線 形 制 約}

しかし単純に式 (1)の行列分解を考えるだけでは, ユー ザ, 商品というミクロな情報とカテゴリやグループといっ たマクロな属性情報の関係性が考慮されない, 乥こで, 商 品とカテゴリの対応関係を示す行列 $W$ を用いて商品特徵 行列 $\boldsymbol{B}$ とカテゴリ特徵行列 $\boldsymbol{C}$ の間に線形制約を導入す る. 同樣にユーザとグループの対応関係を示す行列 $\boldsymbol{V}$ を 用いてユーザ特徵行列 $\boldsymbol{A}$ とグループ特徵行列 $\boldsymbol{D}$ の間に 線形制約を導入する.線形制約は具体的に次式で与える.

$\boldsymbol{W}^{T} \boldsymbol{B}=\boldsymbol{C}, \boldsymbol{V}^{T} \boldsymbol{A}=\boldsymbol{D}$.

この制約により,カテゴリ特徵行列 $\boldsymbol{C}$ の要素 $c_{k r}$ の值が カテゴリ $k$ に所属する商品 $j$ のクラスタ $r$ への寄与度の 和 $\sum_{j} w_{j k} b_{j r}$ と等しくなる. したがって, 図 1 に示したよ うに, 各クラスタにおいてあるカテゴリに属する商品の 寄与度が大きいクラスタは, 弚のカテゴリ自体の寄与度 が大きい值をとるという性質を満たした出力が得られる ことになる. グループ特徵行列 $\boldsymbol{D}$ においても同樣である.

\section{$4 \cdot 3$ 定 式 化}

式 (1) の近似 $\approx$ の尺度には, ユークリッド距離を利用 した

$\mathcal{D}_{E U}\left(\boldsymbol{X} \| \boldsymbol{A} \boldsymbol{B}^{T}\right):=\sum_{(i, j)}\left(x_{i j}-\sum_{r} a_{i r} b_{j r}\right)^{2}$,
や一般化カルバックライブラーダイバージェンスに基づく $\mathcal{D}_{K L}\left(\boldsymbol{X} \| \boldsymbol{A} \boldsymbol{B}^{T}\right):=\sum_{(i, j)}\left(x_{i j} \log \frac{x_{i j}}{\sum_{r} a_{i r} b_{j r}}-x_{i j}+\sum_{r} a_{i r} b_{j r}\right)$,

などが利用され，適用データに応じて使い分けられてい る.これらをまとめて $\mathcal{D}_{(.)}$と書く.

式 (2) で定める制約条件の下, 式 (1) の行列分解を行う 手法として提案手法を定式化する. 目的関数を,

$\mathcal{L}(\boldsymbol{X}, \boldsymbol{Y}, \boldsymbol{Z} \mid \boldsymbol{A}, \boldsymbol{B}, \boldsymbol{C}, \boldsymbol{D})$

$=\mathcal{D}_{(\cdot)}\left(\boldsymbol{X} \| \boldsymbol{A} \boldsymbol{B}^{T}\right)+\mathcal{D}_{(\cdot)}\left(\boldsymbol{Y} \| \boldsymbol{A} \boldsymbol{C}^{T}\right)+\mathcal{D}_{(\cdot)}\left(\boldsymbol{Z} \| \boldsymbol{B} \boldsymbol{D}^{T}\right)$,

で定義し, 行列 $A, B, C, D$ を出力とする提案手法を次の 最適化問題として定式化する.

$$
\begin{array}{rl}
\min _{\boldsymbol{A}, \boldsymbol{B}, \boldsymbol{C}, \boldsymbol{D}} & \mathcal{L}(\boldsymbol{X}, \boldsymbol{Y}, \boldsymbol{Z} \mid \boldsymbol{A}, \boldsymbol{B}, \boldsymbol{C}, \boldsymbol{D}) \\
\text { s.t. } \boldsymbol{A}, \boldsymbol{B}, \boldsymbol{C}, \boldsymbol{D} \geq 0, \boldsymbol{W}^{T} \boldsymbol{B}=\boldsymbol{C}, \boldsymbol{V}^{T} \boldsymbol{A}=\boldsymbol{D} .
\end{array}
$$

関連研究で述べた NMMF は提案手法との関連性が高 く, 提案手法からユーザ-グループ対応行列, 商品-カテゴ リ対応行列を利用した線形制約条件を取り除くと NMMF の定式化とほぼ一致する. 正確には, ハイパーパラメタ $\alpha, \beta$ を用いて NMMF の目的関数は次式で定義される.

$$
\begin{aligned}
& \mathcal{L}_{\alpha, \beta}^{N M M F}(\boldsymbol{X}, \boldsymbol{Y}, \boldsymbol{Z} \mid \boldsymbol{A}, \boldsymbol{B}, \boldsymbol{C}, \boldsymbol{D}) \\
& =\mathcal{D}_{(\cdot)}\left(\boldsymbol{X} \| \boldsymbol{A} \boldsymbol{B}^{T}\right)+\alpha \mathcal{D}_{(\cdot)}\left(\boldsymbol{Y} \| \boldsymbol{A} \boldsymbol{C}^{T}\right)+\beta \mathcal{D}_{(\cdot)}\left(\boldsymbol{Z} \| \boldsymbol{B} \boldsymbol{D}^{T}\right) .
\end{aligned}
$$

ハイパーパラメタ $\alpha, \beta$ の值が大きいほど行列 $\boldsymbol{Y}, \boldsymbol{Z}$ の因 子分解の精度が重視される. NMMF のハイパーパラメタ の最適化にはクロスバリデーションが利用されている.

\section{5. 推定アルゴリズム}

この章では定式化された問題を解く効率的なアルゴリ ズムを導く.この章では, 購買データにおいて用いられる ことの多い $\mathcal{D}_{K L}$ を近似の尺度として採用した際のアル ゴリズムの導出を行う. $\mathcal{D}_{K L}$ の最小化を達成する行列 $\boldsymbol{A}$, $\boldsymbol{B}$ は購買行列の各要素 $x_{i j}$ がポアソン分布

$$
\begin{aligned}
& \mathcal{P O}\left(x_{i j} \mid \sum_{r} a_{i r} b_{j r}\right) \\
& :=\exp \left(-\sum_{r} a_{i r} b_{j r}+x_{i j} \log \left(\sum_{r} a_{i r} b_{j r}\right)-\log \Gamma\left(x_{i j}+1\right)\right),
\end{aligned}
$$

にしたがって得られているとモデリングした際の尤度関 数の最大化を達成する $A, B$ と等価であることが知られ ている

アルゴリズムの導出には, 補助関数法を用いる. 補 助変数 $S=\left\{s_{i j r}\right\}, T=\left\{t_{i k r}\right\}, U=\left\{u_{m j r}\right\},\left(\sum_{r} s_{i j r}=\right.$ $1(\forall i, j), \sum_{r} t_{i k r}=1(\forall i, k), \sum_{r} u_{m j r}=1(\forall m, j)$ を導入 し, 目的関数 $\mathcal{L}$ から定数項を除去して得られる関数, この 
関数の上界 $\overline{\mathcal{L}}$ を Jensen の不等式により求めると,

$\overline{\mathcal{L}}(\boldsymbol{X}, \boldsymbol{Y}, \boldsymbol{Z} \mid \boldsymbol{A}, \boldsymbol{B}, \boldsymbol{C}, \boldsymbol{D})$

$$
\begin{aligned}
= & \sum_{(i, j)}\left(\sum_{r} a_{i r} b_{j r}-x_{i j} \sum_{r} s_{i j r} \log \frac{a_{i r} b_{j r}}{s_{i j r}}\right) \\
& +\sum_{(i, k)}\left(\sum_{r} a_{i r} c_{k r}-y_{i k} \sum_{r} t_{i k r} \log \frac{a_{i r} c_{k r}}{t_{i k r}}\right) \\
& +\sum_{(m, j)}\left(\sum_{r} d_{m r} b_{j r}-z_{m j} \sum_{r} u_{m j r} \log \frac{d_{m r} b_{j r}}{u_{m j r}}\right),
\end{aligned}
$$

が得られる. この式を最小化する補助変数 $\boldsymbol{S}, \boldsymbol{T}, \boldsymbol{U}$ と行 列 $\boldsymbol{A}, \boldsymbol{B}, \boldsymbol{C}, \boldsymbol{D}$ を弚れ光れ求めることにより, 次の乗法更 新則が導かれる.

$$
\begin{aligned}
a_{i r} & \leftarrow a_{i r} \frac{\sum_{j} \frac{x_{i j}}{\hat{x}_{i j}} b_{j r}+\sum_{k} \frac{y_{i k}}{y_{i k}} c_{k r}+\sum_{j} \sum_{m} v_{i m} \frac{z_{m j}}{z_{m j}} b_{j r}}{\left(\sum_{m} v_{i m}+1\right) \sum_{j} b_{j r}+\sum_{k} c_{k r}}, \\
b_{j r} & \leftarrow b_{j r} \frac{\sum_{i} \frac{x_{i j}}{\hat{x}_{i j}} a_{i r}+\sum_{i} \sum_{k} w_{j k} \frac{y_{i k}}{\hat{y}_{i k}} a_{i r}+\sum_{m} \frac{z_{m j}}{z_{m j}} d_{m r}}{\left(\sum_{k} w_{j k}+1\right) \sum_{i} a_{i r}+\sum_{m} d_{m r}}, \\
c_{k r} & \leftarrow \sum_{j} w_{j k} b_{j r}, \quad d_{m r} \leftarrow \sum_{i} v_{i m} a_{i r} .
\end{aligned}
$$

行列 $A, B, C, D$ を逐次的に更新することで, 所望の出 力を得る事ができる. また, 明らかに各行列の初期值を非 負の值に設定すれば, 更新式右辺の分子・分母は常に正で あり, 非負值制約が保たれることが分かる.なお, 以後の 実験では 50 回の反復計算を行った .

図 4 に図 3, 図 2 を入力としたときの提案手法の適用例 を示す. 提案手法は前述したようにミクロな情報とマクロ な属性情報が混在するデータ集合を非負值行列因子分解 手法であるため, 以後 Non-negative Micro Macro Mixed Matrix Factorization(NM4F) と呼ぶこととする.

\section{6. 実 験}

実験では, 2013 年 1 月 1 日から 2013 年 12 月 31 日まで の 1 年間に収集された調查パネルデータを利用する.デー タ中の全体傾向を把握する目的で, 購買履歴中の購買数の

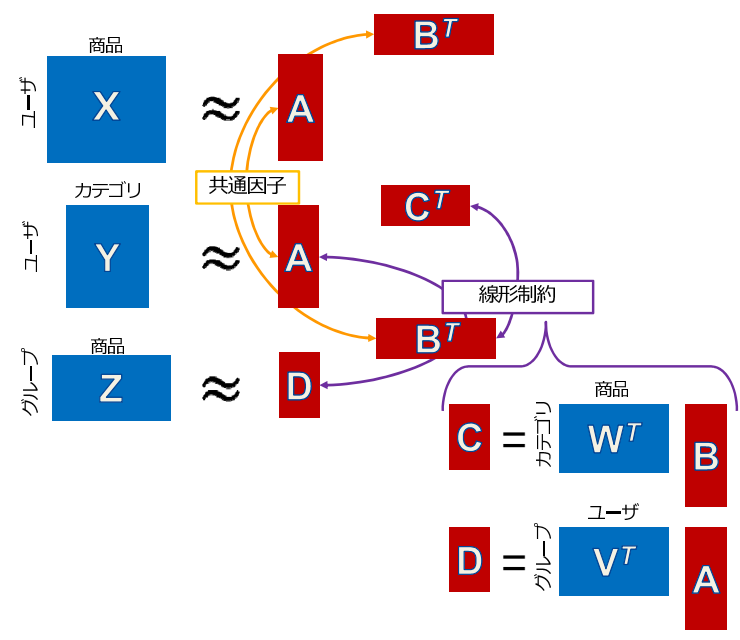

図 4 NM4F のイメージ
多い上位 500 人のユーザ(全体ユーザ約 5,000 人) と出現頻 度の多い啫好品上位 10,000 点 (全体商品数約 15 万点) を対 象商品とした. デモグラフィック情報には, 年齢, 性別, 職業 に関する情報を用いる.これにより,利用する入力行列の サイズを定まるユーザ数, 商品数, カテゴリ数, グルーフ数 は光れ光れ $I=500, J=10,000, K=54, M=29$ となっ た. 作成した行列 $X$ は非ゼ口要素の全体に占める割合 が約 $2.9 \%$ 程度 (ユーザー人当たり)購入商品種類数約 290 点)であり, スパースな行列を解析する実験設定であると いえる.

\section{$\mathbf{6} \cdot \mathbf{1}$ 定 量 評 価}

はじめに提案手法の定量評価を行う.ここでは, 作成し た行列 $\boldsymbol{X}, \boldsymbol{Y}, \boldsymbol{Z}$ のうち, $\boldsymbol{X}$ の非ゼ口要素の一部を隐蔽し て(欠損させて) テストデータ, 噯蔽されていない要素を 学習データとして, 隠蔽された值を正しく推定できるかを 検証する. $\boldsymbol{Y}, \boldsymbol{Z}$ の值と属性情報を定める関係行列 $\boldsymbol{V}, \boldsymbol{W}$ を利用することで既存手法である VBNMF[Cemgil 08] どと比較して推定性能は向上することが期待される.さ らにNMMF[Takeuchi 13] との比較も合わせて行う.

学習データとテストデータの組を計 5 組作成し, 各ク ラスタ数における推定精度を求める. 推定精度を計る基 準には, 次のように計算される, テストデータに対する対 数尤度 (Test Log-likelihood) を利用する.

Test Log-likelihood $=\sum_{(i, j) \in \text { Test }} \log \mathcal{P O}\left(x_{i j} \mid \hat{x}_{i j}\right)$

この值が大きいほど隠蔽された值を正しく推定できてい ることを表す。なお, VBNMF のハイパーパラメタは文 献 [Cemgil 08] と同じく fixed point iteration による最適 化を行った. NMMFにおける補助行列 $\boldsymbol{Y}, \boldsymbol{Z}$ の重みを調 整するハイパーパラメタは $\alpha=\beta=0.1,0.5,1.0$ の 3 通

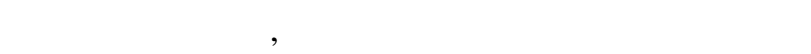
めた.

図 5 に実験結果を示す. 横軸がクラスタ数, 縦軸がテス トデータに対する対数尤度の值である. $\mathrm{nm} 4 \mathrm{f}$ か提案手法,

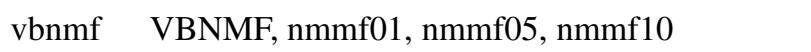
れの NMMFにおけるハイパーパラメタを $0.1,0.5,1.0$ と 設定した際の結果である. エラーバーの長さは標準偏差 を表す. NMMF は nmmf01, nmmf05, nmmf10の关れ ぞれにおける結果から,ハイパーパラメタの設定で推定精 度が大きく異なるという結果が得られているものの, 八 イパーパラメタを 1.0 に設定した際にはクラスタ数 20 の とき比較手法の全てを上回る推定精度を示している. 光 れに対して提案手法 NM4F の結果は, クラスタ数が 10 よ り小さい範囲では nmmf10 の值と同等, またクラスタ数 によらず他の vbnmf, nmmf01, nmmf05 を上回るという 結果が得られている.このことは, 提案手法が NMMFに おける計算コストの高いクロスバリデーションを用いた ハイパーパラメタ選択を行うことなく NMMF の達成可 


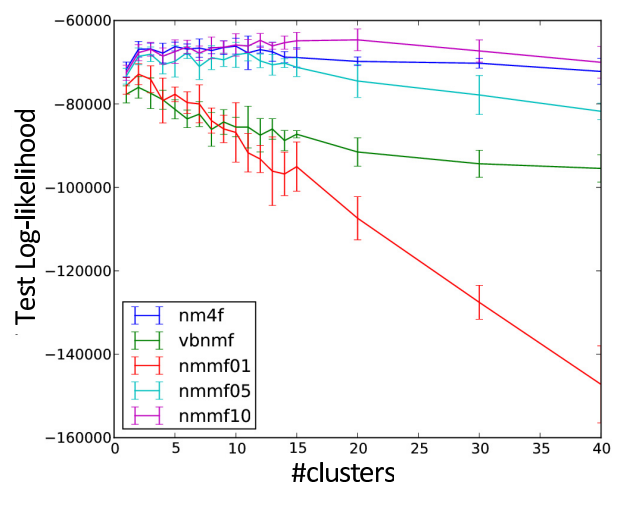

図 5 テストデータに対する対数尤度

能な最高精度と同等程度の推定性能を持つことを示して いるといえる. また, 提案手法は一部のクラスタ数の設定 ではNMMFよりも精度か下回る.この原因は線形制約条 件にある. 提案手法は線形制約条件を与えているため, 同 一クラスタ数の NMMFよりも自由度は低くなっており, あるクラスタ数における対数尤度の意味での最適解が提 案手法で表現できない場合, NMMF の方が推定精度が高 くなる. しかしながら, 提案手法はハイパーパラメタに依 存せず,かつ線形制約を設けながらも NMMF の最高值と 同等の精度を保持していることが分かる.

\section{$6 \cdot 2$ 定 性 評 価}

次に提案手法の定性評価を行う. 定量評価における実 験結果から, 提案手法はクラスタ数 10 のときに予測精度 が最大となり,データの全体傾向を掴むことができてい ることが分かる. 乥こでクラスタ数 10 で提案手法を適用 して得られたクラスタに関して調査を行う.

$\S 1$ グラフ可視化による購買パターン全体の考察

まずはじめに購買パターン全体の傾向に関する考察を 行う. 商品同士の類似度を商品特徵行列 $B$ を用いて算出 し,グラフ可視化を行った. 具体的には, 全商品のうち購 買頻度の高い上位 3,000 点の商品を抽出し, 商品 $j$ のクラ スタ $r$ への寄与度 $b_{j r}$ を正規化した值 $\hat{b}_{j r}=b_{j r} / \sum_{r} b_{j r}$ を用いて, 商品 $j$ と $j^{\prime}$ の商品類似度をコサイン類似度に 基づき次のように算出した.

$\operatorname{Sim}_{j j^{\prime}}=\frac{\sum_{r} \hat{b}_{j r} \hat{b}_{j^{\prime} r}}{\sqrt{\sum_{r} \hat{b}_{j r}^{2} \sum_{r} \hat{b}_{j^{\prime} r}^{2}}}$

この商品類似度に基づき $\operatorname{Sim}_{j j^{\prime}} \geq 0.97$ を満たす商品間 にエッジを張ることでグラフを作成した. 孤立ノードを 除外した 2,304 ノード, 56,211 エッジからなるグラフの 可視化結果が図 6 および図 7 である.

图 6 は, 各商品に対して,$\hat{b}_{j r} \geq 0.3$ となるクラスタ $r$ のみを色付けして描画させている .この結果から, 図左下 のクラスタ 1 とクラスタ 2 から構成される部分グラフ 1 , 図右下のクラスタ 5 などから構成される部分グラフ 2 , 图 中央のクラスタ 9 などの多くのクラスタから構成される 部分グラフ 3 の 3 つ部分グラフから構成されているこ

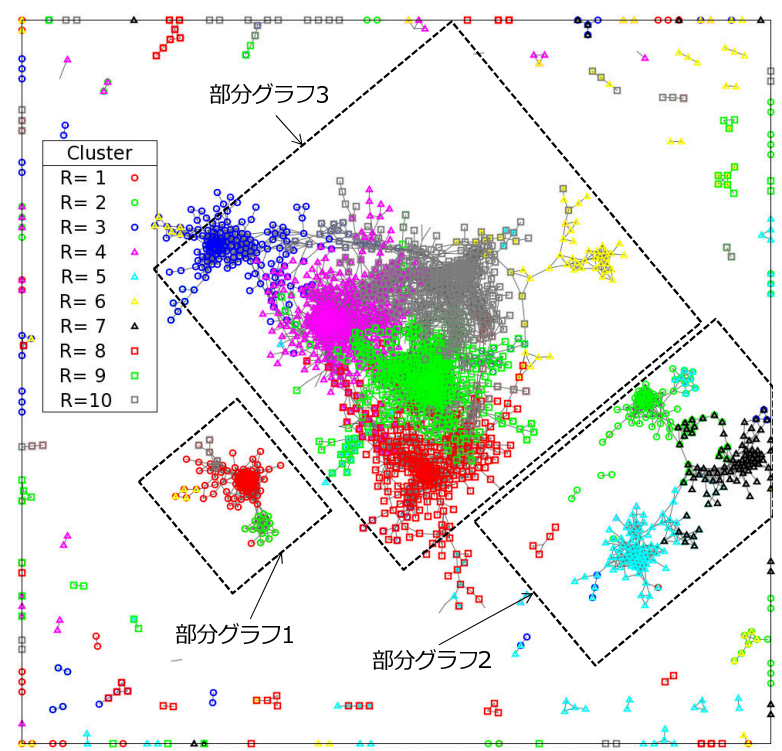

図 6 クラスタ毎に色分けしたグラフ可視化結果

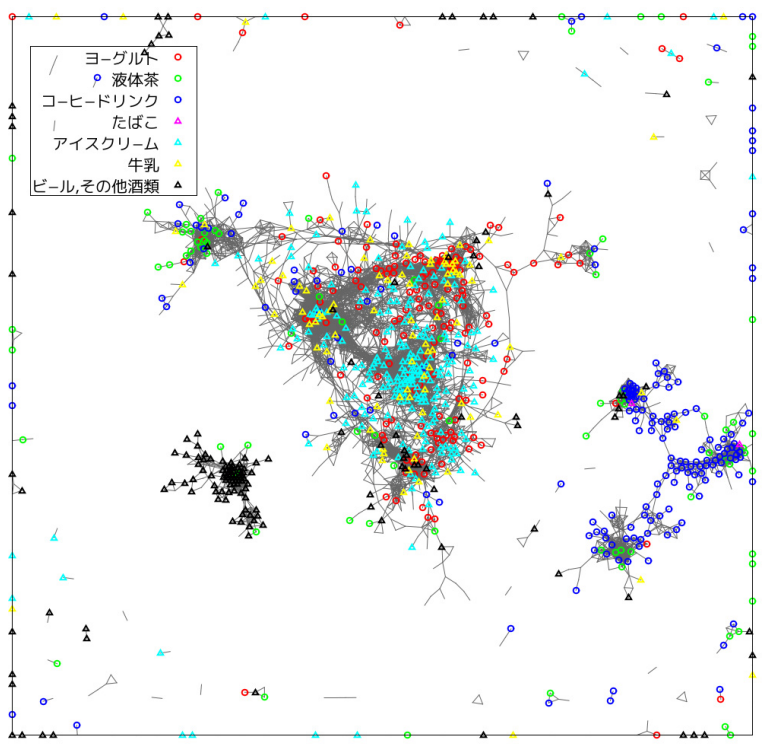

図 7 カテゴリ毎に色分けしたグラフ可視化結果

とが読み取れる. これは抽出された 10 のクラスタは, 大 きく 3 つのクラスタ群に分類できることを示している.

さらに図 7 では, 商品カテゴリから特徵的な 7 カテゴ リ (“ヨーグルト”, “液体茶”, “コーヒードリンク”, “たば こ”, “アイスクリーム”, “牛乳”, “ビール, 光の他酒類”) を 抽出し, 各商品の所属カテゴリ毎に色分けして表示して いる.この結果から, 部分グラフ 1 では “ビール, 弚の他 酒類”, 部分グラフ 2 では “コーヒードリンク”が主要な力 テゴリとなっていること, 部分グラフ 3 は各カテゴリの 商品が混在していることが分かる.

$\S 2$ 整合性と解釈性：購買パターンに関する定性的評価 次に抽出された各個別の購買パターンに関する考察を

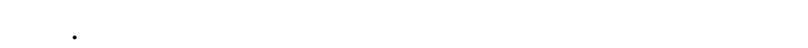

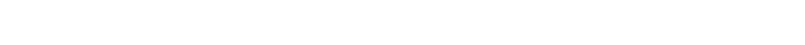


1 (男性・アルコール)，クラスタ５（男性・コーラ・ コーヒー)，クラスタ 9 (女性・デザート) として得ら れた各クラスタ毎に, 商品, カテゴリ, グループのクラス 夕寄与度の値の大きい上位 15 件を抽出し, 図 8 , 図 9, 図 10 に示した . 各図において上段か提案手法, 下段か対比 手法 NMMF (nmmf10, $\alpha=\beta=1.0)$ の結果を示し , 提 案手法と対比手法共にクラスタ数を $R=10$ とした .な お，商品名は情報開示の都合上，カテゴリ名で置き換え て表示している. 各図のヒストグラムの大きさは寄与度 の值を示し , item-feature $(\boldsymbol{A})$, category-feature $(\boldsymbol{C}$ お よび $\left.\boldsymbol{W}^{T} \boldsymbol{B}\right)$, group-feature $\left(\boldsymbol{D}\right.$ および $\left.\boldsymbol{V}^{T} \boldsymbol{A}\right)$ として表 示している. このとき, 提案手法では式 (2) の制約の下， $\boldsymbol{W}^{T} \boldsymbol{B}=\boldsymbol{C}$ および $\boldsymbol{V}^{T} \boldsymbol{A}=\boldsymbol{D}$ が成立している．一方， NMMF ではユーザ-グループおよび商品-カテゴリ間の属 性に制約式 (2) を与えないために，一般には等号が成立せ ず, $\boldsymbol{W}^{T} \boldsymbol{B} \neq \boldsymbol{C}$ および $\boldsymbol{V}^{T} \boldsymbol{A} \neq \boldsymbol{D}$ となる. 光のため, 本 研究では提案手法との比較のため, NMMF の categoryfeature および group-feature の出力結果 $C$ および $D$ に 対しては, NMMF の本来の出力ではない $\boldsymbol{W}^{T} \boldsymbol{B}, \boldsymbol{V}^{T} \boldsymbol{A}$ を用いたヒストグラムを合わせて図示した .

例えば図 9 のクラスタ 5 の group-feature に注目する と, NMMF の出力では,『グルーブ寄与度 $(\boldsymbol{D})$ より “自営 業・個人事業主” の寄与度が 2 番目に大きいという結果が 得られたが, ユーザ推定結果 $(\boldsymbol{A})$ から構築したグループ 寄与度 $\left(\boldsymbol{V}^{T} \boldsymbol{A}\right)$ では, “正社員”や “F2 層（女性 35 歳〜 49 歳) ”の方が寄与度が大きく, “自営業・個人事業主” の寄与度は比較的小さい』という結果が得られているこ とが分かる. これは, 本来 “正社員”の寄与度が “自営業・ 個人事業主” の寄与度よりも本来大きいクラスタである ことを推定値 $(\boldsymbol{C})$ は表現できておらず, 両者の順番を逆 転させた結果を出力してしまっていることが分かる.

また単純に順番が入れ替わるだけでなく, クラスタの 上位に本来出現するべきグループおよびカテゴリが現れ なくなる場合もある. 図 11 に NMFF の出力クラスタの category-feature の並び順を $\boldsymbol{W}^{T} \boldsymbol{B}$ の大きい順に並び 替えて表示したものを示す. 例えば, 図 11 のクラスタ 9 に注目すると, “ヨーグルト”と“コーヒードリンク”カテ ゴリの推定值 $(\boldsymbol{C})$ は商品寄与度の和に基づく值 $\left(\boldsymbol{W}^{T} \boldsymbol{B}\right)$ よりも非常に小さい值となっている. したがって, 先ほど と同樣に “ヨーグルト”カテゴリの商品の寄与度が本来大 きいクラスタであることを推定值 $(\boldsymbol{C})$ は表現できておら ず, 図 10 の NMMF の出力において“ヨーグルト”が上位 カテゴリに現れない結果を出力している.

上記の $2 つ の$ 例は $\ulcorner\mathrm{NMMF}$ は NMF と比較して精度 は上がるが, 分析結果の整合性が失われる」ということ を示している．一方で本提案手法では，属性関係を考慮 して線形制約を導入することによって，NMMF と同等の 分析精度を保ちながら, 整合性を失わずに分析を可能と している .
$\S 3$ マーケティングの現場における利用に関する考察

最後に本技術のマーケティングの現場における利用方 法に関して考察する. 提案手法のクラスタリング結果は 商品とカテゴリ, 属性とユーザを寄与度の整合性を担保 したうえで出力されたものであるから, 提案手法は 1 章 章で述べた現場の作業工程 Act1,2 を人手を介さず一挙に 行う技術であるとみなすことができる. 提案手法の出力 を利用した施策立案の例として, 栄養ドリンクの販売促 進施策を考える場合を考える. 図 9 の示す提案手法の出 カクラスタ 5 に着目すると, category-feature よりクラ スタ 5 には栄養ドリンクが上位カテゴリに含まれ，また それ以外にもコーヒードリンク, コーラ, スポーツドリン ク, 液体茶が上位であることが分かる.よって, 例えばそ れらカテゴリの商品と栄養ドリンクを併売する際に金額 を割引くという施策が考えられる. 前述の寄与度の整合 性からクラスタ中に該当カテゴリの商品が存在すること は保証されており, 商品レベルで割引対象商品を決める ことも可能である. また, 上記割引内容の告知を行う際に は, group-feature の上位属性である M2 層, 男性 30 代の ユーザにリーチできるように広告出稿, DM 配信を行う というアプローチもこのクラスタリング結果から考える ことが可能である. このように提案手法の利用によって, 施策立案を行うまでに必要となる作業工程 Act1,2 を自動 化することが可能となり, 現場の負担軽減や人手を介さ ないことによる作業工程 Act1,2 中の主観の排除が可能と なる。

\section{7. ま と め}

本研究では, 属性間の関係性を考慮した非負値多重行 列因子分解法を提案し, 調査パネルデータを用いた消費 者行動パターン抽出を行った. 定量評価から, 提案手法は NMMF の最高精度と同等程度の推定性能を持つことが 確かめられた. また, 定性評価から, 提案手法は因子行列 間の線形制約を導入することで, 既存手法では不可能で あったパターン内のマクロな属性情報とミクロな情報の 整合性を保持したパターン出力が可能であることを確認 した. したがって提案手法の出力はマーケティングの現 場等でデータ解析の非専門家がパターンの解釈を行う際 に, パターン内の整合性がとれないことにより解釈不可 能となることを避けることができ,マーケティングの現場 での施策立案に利用できる. 非専門家による出力結果の 主観評価を実施することや, パターン内の整合性を保つ こと以外に出力結果に要求される性質を見出すこと・手 法を創出していくことは今後の課題である.

謝辞

本研究で用いた調査パネルデータ「SCI」に関して株 式会社インテージの協力を得た.ここに記して感謝する. 


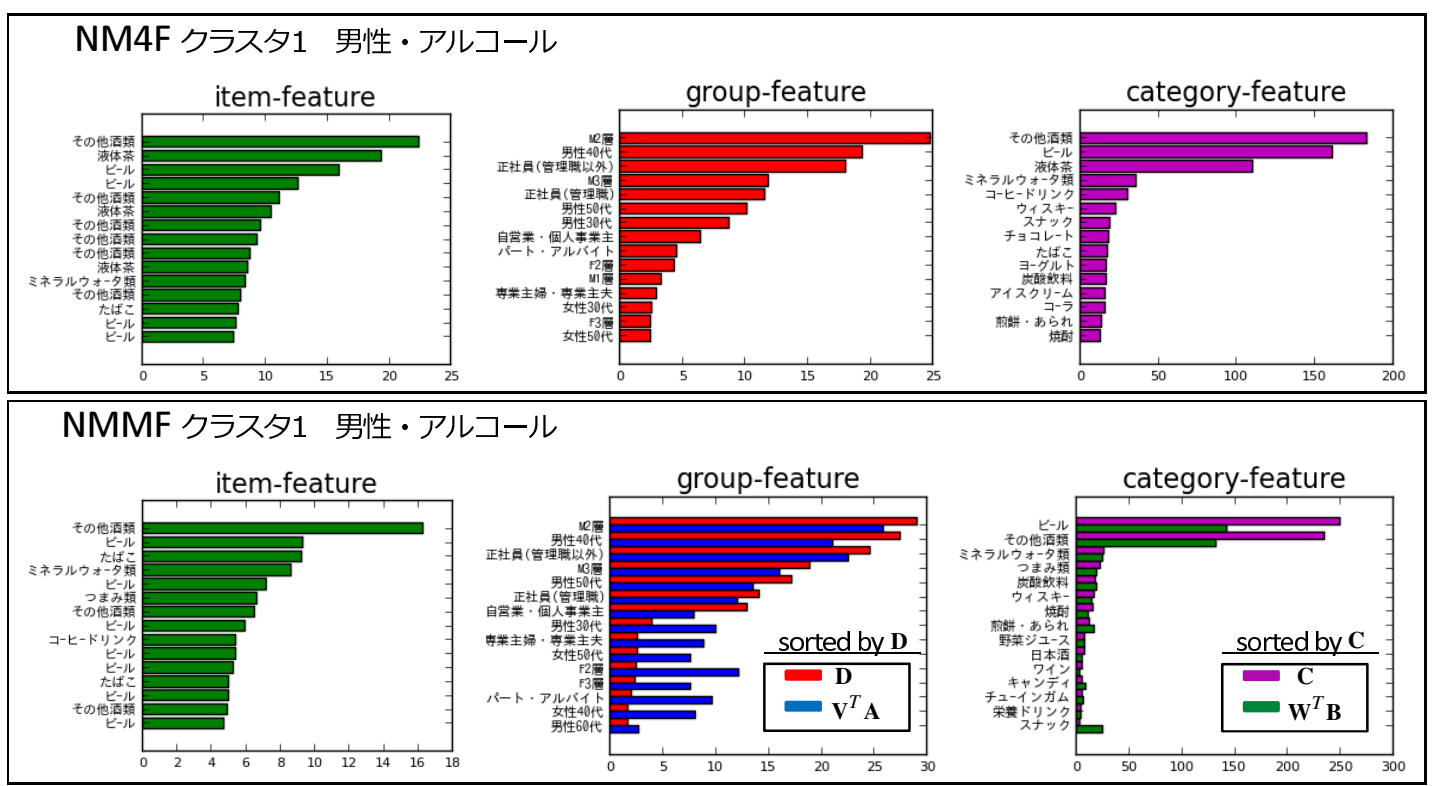

図 8 クラスタ数 10 におけるクラスタリング結果产の 1. 上が提案手法, 下が NMMF による結果を表す.

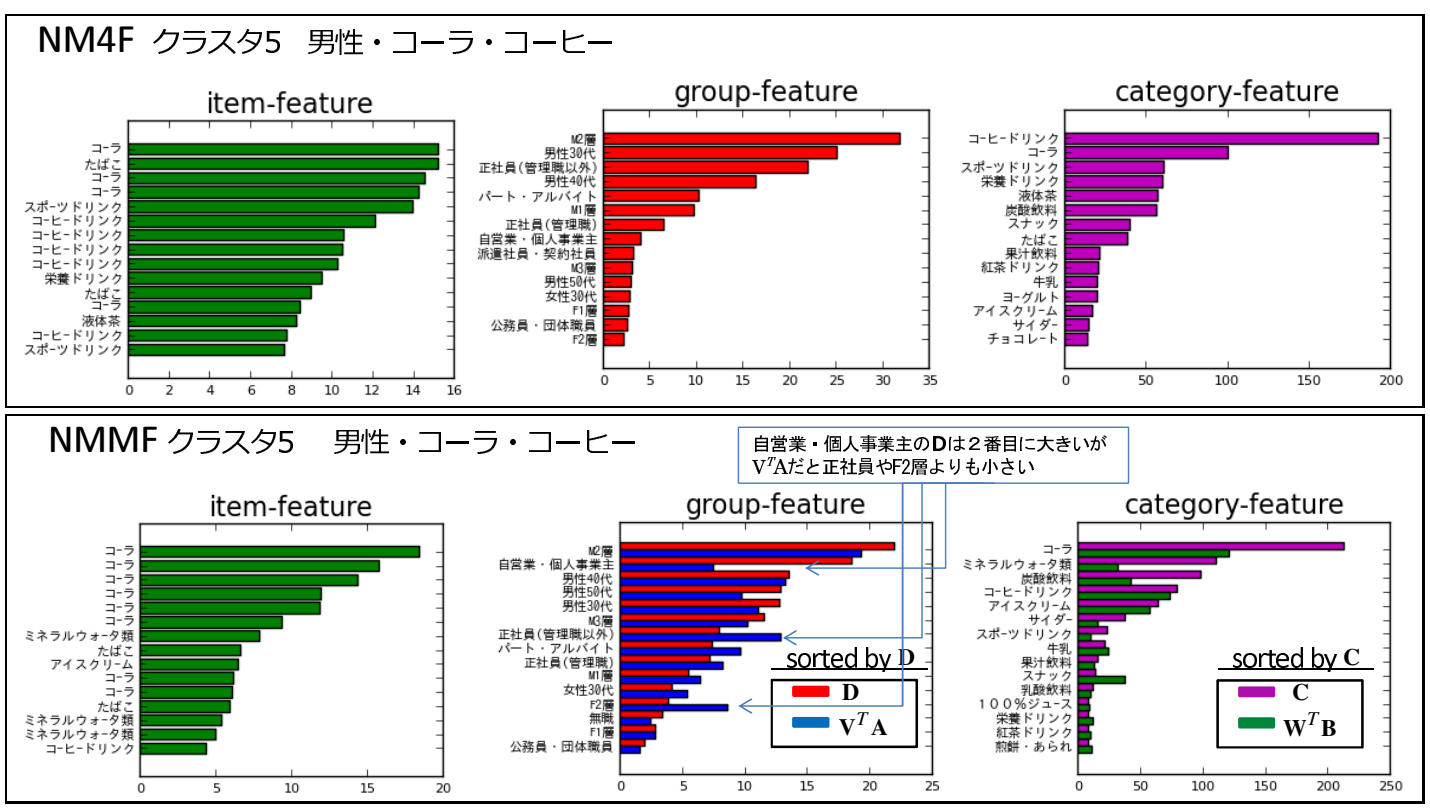

図 9 クラスタ数 10 におけるクラスタリング結果产の 2. 上が提案手法, 下が NMMF による結果を表す. 

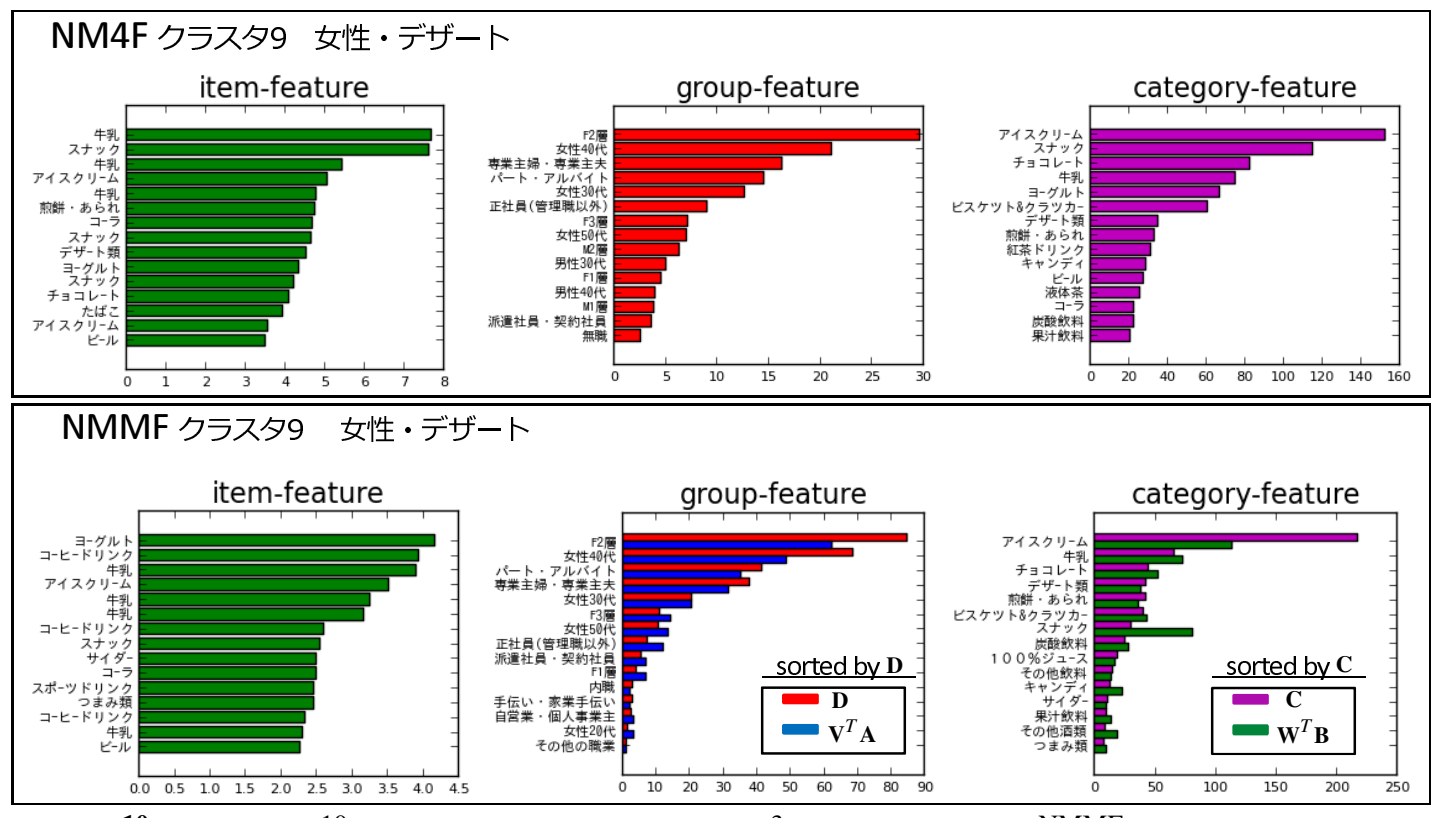

図 10 クラスタ数 10 におけるクラスタリング結果产の 3. 上が提案手法, 下が NMMF による結果を表す.

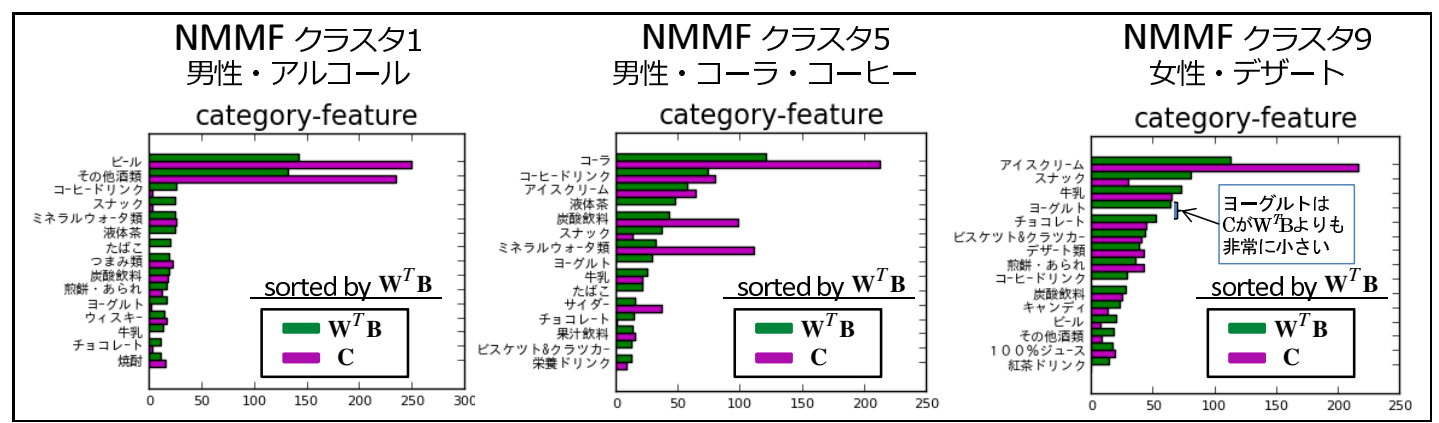

図 11 NMMF によるクラスタリング結果の category-feature を $\boldsymbol{W}^{T} \boldsymbol{B}$ の大きい順にソートした出力.

\section{$\diamond$ 参 考 文 献 $\diamond$}

[阿部 05] 阿部誠, 近藤 文代. マーケティングの科学一POS デー 夕の解析一, 朝倉書店, 2005.

[Blei 03] D. M. Blei, A. Y. Ng, and M. I. Jordan. Latent dirichlet allocation, the Journal of Machine Learning Research, 3, pp. 993-1022, 2003.

[Cai 11] D. Cai, X. He, J. Han, and T. S. Huang. Graph regularized nonnegative matrix factorization for data representation, IEEE Transactions on Pattern Analysis and Machine Intelligence, 33.8, pp. 15481560, 2011.

[Cemgil 08] A. T. Cemgil. Bayesian inference in non-negative matrix factorisation models, Technical Report CUED/F-INFENG/TR.609, University of Cambridge, 2008.

[Cichocki 09] A. Cichocki, R. Zdunek, A. H. Phan, and S. I. Amari. Nonnegative matrix and tensor factorizations: applications to exploratory multi-way data analysis and blind source separation, John Wiley \& Sons, 2009.

[Ding 08] C. Ding, L. Tao, and P. Wei. On the equivalence between non-negative matrix factorization and probabilistic latent semantic indexing, Computational Statistics \& Data Analysis, 52.8, pp. 39133927,2008

[Hoffman 99] T. Hofmann. Probabilistic latent semantic indexing, Proceedings of the 22nd annual international ACM SIGIR conference on Research and development in information retrieval, pp. 50$57,1999$.

[Hoffman 10] M. Hoffman, D. M. Blei, and P. R. Cook. Bayesian nonparametric matrix factorization for recorded music, In Proc. 27th International Conference on Machine Learning (ICML-10), pp. 439446, 2010.

[幸島 13] 幸島 匡宏, 江崎 健司, 高屋 典子, 澤田 宏. 複数行列の行
列分解に関する一考察, 信学技報, IBISML2013-50, pp. 107-114, 2013.

[Koren 09] Y. Koren, R. Bell, and C. Volinsky. Matrix factorization techniques for recommender systems, Computer, 42.8, pp. 30-37, 2009.

[Lee 99] D. D. Lee and H. S. Seung. Learning the parts of objects by non-negative matrix factorization, Nature, 401.6755, pp. 788-791, 1999.

[Lee 01] D. D. Lee and H. S. Seung. Algorithms for non-negative matrix factorization, Advances in Neural Information Processing Systems, 13, pp. 556-562, 2001.

[Lee 10] H. Lee, J. Yoo, and S. Choi. Semi-supervised nonnegative matrix factorization, IEEE Signal Processing Letters, 17.1, pp. 4-7, 2010.

[Purushotham 12] S. Purushotham, L. Yan, and C-C. J. Kuo. Collaborative Topic Regression with Social Matrix Factorization for Recommendation Systems, In Proc. 29th International Conference on Machine Learning (ICML-12), pp. 759-766, 2012.

[Salakhutdinov 12] R. Salakhutdinov and A. Mnih. Probabilistic matrix factorization. Advances in Neural Information Processing Systems, 21, pp. 1257-1264, 2007.

[澤田 12] 澤田 宏. 非負値行列因子分解 NMF の基礎とデータ/信 号解析への応用, 電子情報通信学会誌, 95.9, pp. 829-833, 2012.

[竹内 12] 竹内 孝, 石黑勝彦, 木村昭悟, 澤田 宏. sNMF: 非負值制 約下における複数行列の同時分解法〜ソーシャルメディア解析 を応用例として〜，信学技報, IBISML2012-43, pp. 67-74, 2012.

[Takeuchi 13] K. Takeuchi, K. Ishiguro, A. Kimura, and H. Sawada Non-negative Multiple Matrix Factorization, In Proc. 23rd International Joint Conference on Artificial Intelligence (IJCAI-2013), pp.1713-1720, 2013. 
〔担当委員 : 鳥海 不二夫〕

2014 年 10 月 8 日 受理

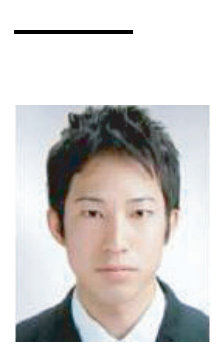

者 紹介

幸島 匡宏

2009 年, 東京工業大学工学部情報工学科卒業. 2012 年, 同 大学院総合理工学研究科知能システム科学専攻修士課程修 了. 同年, 日本電信電話株式会社入社. 以来 NTT サービス エボリューション研究所にて, 機械学習およびデータマイ ニングの研究に従事.

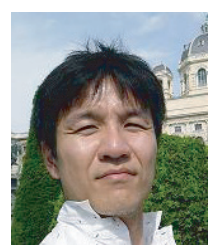

松林 達史

2000 年, 京都大学理学部物理学科卒業. 2002 年 10 月より

2 年半, 理化学研究所非常勤研究員. 2005 年, 東京工業大学 大学院理工学研究科地球惑星科学専攻博士課程修了. 同年, 日本電信電話株式会社入社. 以来, NTT コミュニケーショ ン科学基礎研究所, NTT サービスエボリューション研究所 にて,グラフ可視化および機械学習の研究開発に従事. 博士 (理学). 情報処理学会会員.

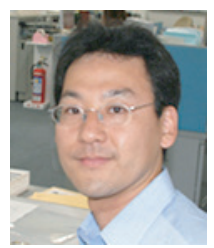

澤田＼cjkstart宏

1991 年, 京都大学工学部情報科卒業. 1993 年, 同大学院工 学研究科情報工学専攻修士課程修了. 同年, 日本電信電話 株式会社入社. 以来, 同社コミュニケーション科学基礎研究 所にて，VLSI 向け CAD およひ計算機アーキテクチャの

研究に従事 . 2000 年より, 信号処理, 特にブラインド音源 分離の研究に従事. 2009 年より, 知能創発環境研究グルー プリーダ. 2013 年より,サービスエボリューション研究所 ヒューマンアナリシスプロジェクトグループリーダ. 2001

年, 京都大学博士 (情報学). 電子情報通信学会, 日本音響学会, IEEE 各会員. 